\title{
Preparation of microcapsule-supported Pd catalyst using a microfluidic platform
}

\author{
Ying Liu, Yangcheng Lü*, Guangsheng Luo \\ State Key Laborotary of Chemical Engineering, Department of Chemical Engineering, Tsinghua University, Beijing 100084, China
}

\section{A R T I C L E I N F O}

Article history:

Received 29 April 2013

Accepted 30 May 2013

Published 20 September 2013

\section{Keywords:}

Microcapsule

Palladium

Supported catalyst

Microfluidic technique

Particle size control

Suzuki coupling reaction

Catalytic activity

\begin{abstract}
A B S T R A C T
A phosphine-functionalized polystyrene microcapsule with hundreds of microns in size was prepared using a microfluidic platform. The size distribution was narrow and the average size could be adjusted in the range 300-400 $\mu \mathrm{m}$. The morphology and composition of the microcapsules were characterized using scanning electron microscopy, energy-dispersive X-ray spectroscopy, and inductively coupled plasma atomic emission spectroscopy. The results verified the effectiveness of the strategy we proposed for preparing uniform microcapsules with stable Pd immobilization. A Suzuki coupling reaction between aryl halides and phenylboronic acid was used as the model to evaluate their catalytic activity after $\mathrm{Pd}\left(\mathrm{PPh}_{3}\right)_{4}$ immobilized onto the microcapsule. It was found that the catalytic activity of microcapsule-supported Pd was always higher than that of the corresponding homogeneous catalyst, and was similar with that of the literature reported microcapsule-supported catalyst with about 7-8 $\mu \mathrm{m}$ particle size. Microcapsule-supported Pd with microcapsules of hundreds of microns in size, being easy to recover, showed good reusability and undetected active species loss, its productivity effect and controllability of the microcapsule-supported Pd catalyst were also expected to benefit from continuous preparation using the microfluidic platform. Moreover, they could be potentially exploited in a fixed-bed reactor with high catalyst density and good mechanical stability.
\end{abstract}

(c) 2013, Dalian Institute of Chemical Physics, Chinese Academy of Sciences. Published by Elsevier B.V. All rights reserved.

\section{Introduction}

Microencapsulated catalysts, a type of so-called heterogenized homogeneous catalyst [1], have drawn attention in both research and applications because of their potential advantages in terms of catalytic activity, stability and preparation costs, compared with traditional heterogeneous catalysts. Transition metals were supported by microcapsules with functional groups have been widely used for catalyzing $\mathrm{C}-\mathrm{C}$ bond formation reactions [2-4], and have exhibited considerable catalytic performance in terms of activity, selectivity, and reusability. For example, Nishiro et al. [5] developed the polymer in- carcerated (PI) method for the immobilization of $\mathrm{Pd}\left(\mathrm{PPh}_{3}\right)_{4}$ on polystyrene-based polymers to afford the desired catalyst. When PI-prepared Pd was used in the Suzuki coupling of aryl halides with arylboronic acid, the yields of coupling products reached $84 \%-96 \%$ after refluxing for $4 \mathrm{~h}$ in toluene $/ \mathrm{H}_{2} \mathrm{O}$ as the solvent. Because the properties of size and morphology of the supporting microcapsules will be effect on their catalytic activities, it is necessary to regulate their structural characteristics such as size and morphology for the process mechanism investigation and catalyst optimization. Recently, Liu et al. [6] reported the preparation of a microcapsule-supported Pd catalyst with a narrow size distribution in the range 7-10 $\mu \mathrm{m}$ (denoted

*Corresponding author. Tel/Fax: +86-10-62773017; E-mail: luyc@mail.tsinghua.edu.cn

This work was supported by the National Natural Science Foundation of China $(21036002,21176136)$ and the Postdoctoral Science Foundation of China (2012M520295).

DOI: 10.1016/S1872-2067(12)60630-5 | http://www.sciencedirect.com/science/journal/18722067 | Chin. J. Catal., Vol. 34, No. 9, September 2013 
by Mic-Pd in the following). Droplets containing 4-diphenylphosphinostyrene as the monomer were prepared using the Shirasu porous glass (SPG) membrane emulsification technique $[7,8]$, and then converted to microcapsules by subsequent suspension polymerization in a beaker. After Pd loading by contacting with a homogeneous Pd catalyst solution, the microcapsules exhibited high and stable catalytic activity for the Suzuki coupling reaction. However, in this preparation process, both emulsification and polymerization were conducted in batch mode, so the morphology and size of the microcapsules might be uncontrolled because of the relatively long emulsion collection time and the high temperature needed to initiate polymerization.

In recent decades, microfluidic technologies based on the precise control of a fluid at the microscale have been developing quickly [9]. By using these techniques in liquid-liquid [10], gas-liquid [11], and other multiphase systems [12], the dispersed phase can be highly controlled in terms of shape, composition and structure, and this can be used to prepare microspheres [13,14] or pharmaceutical microcapsule [15] with narrow size distributions (coefficient of variance less than 5\%), while achieving control of the molecular weight of the polymer [16] and the complicated inner structure of the microcapsules [17].

In this work, using a controllable reaction platform based on microfluidic technologies, we attempted to establish a continuous and quick method for the preparation of microcapsule-supported Pd catalysts of uniform particle size. In-situ and continuous droplet generation and polymerization in microchannels enabled the particle size of the microcapsules to be adjusted flexibly and accurately within the range of 300-400 $\mu \mathrm{m}$. The effect of particle size on the catalytic activity was explored after Pd immobilization using the Suzuki coupling reaction of aryl halides with boronic acid (Scheme 1) as a model. Finally, the reusability of these microcapsule-supported Pd catalysts was also tested.

\section{Experimental}

\subsection{Synthesis of 4-diphenylphosphinostyrene}

The procedure for the synthesis of 4-diphenylphosphinostyrene has been reported elsewhere [18]. A brief description is as follows. About $1.46 \mathrm{~g}$ ( $60 \mathrm{mmol}$ ) magnesium powder (AR, Sinopharm Group Co., Ltd., China) was added to a

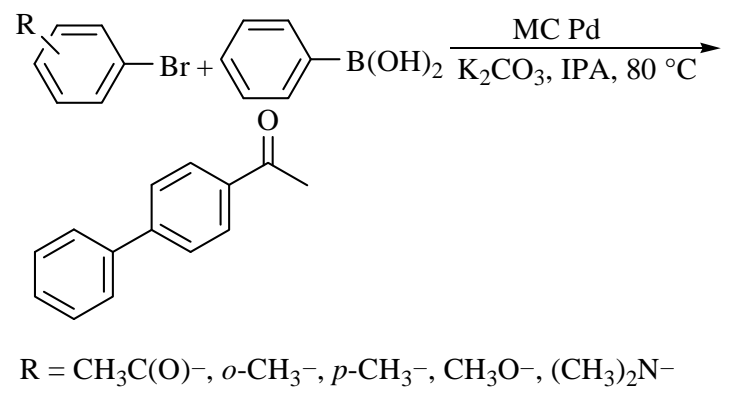

Scheme 1. Suzuki coupling reaction of aryl bromides and phenylboronic acid. 250-ml three-necked bottle equipped with a constant-pressure dropping funnel. Under high-purity $\mathrm{N}_{2}$, a solution of 4-bromostyrene $(6.5 \mathrm{ml}, 50 \mathrm{mmol}$, Shanghai Chang-Gen Chemical Technology Co., Ltd., chemical grade) in dry tetrahydrofuran (THF, $30 \mathrm{ml}$, AR, Beijing Chemical Reagents Factory) was added to the dropping funnel, and then slowly dropped into the three-necked bottle at below $40{ }^{\circ} \mathrm{C}$. After the magnesium powder in the bottle had disappeared, a solution of chlorodiphenylphosphine ( $9.4 \mathrm{~g}, 50 \mathrm{mmol})$ in dry THF (20 ml) was added at $-15{ }^{\circ} \mathrm{C}$ within $2 \mathrm{~h}$. After the reaction was complete, the mixture solution was warmed to room temperature, and then adjusted to weak acidity by adding saturated $\mathrm{NH}_{4} \mathrm{Cl}$ aqueous solution. After extraction with ethyl acetate, the organic layer was separated out, sequentially washed with saturated $\mathrm{NaHCO}_{3}$ aqueous solution $(100 \mathrm{ml} \times 2)$ and brine $(100 \mathrm{ml} \times 2)$, dried using $\mathrm{Na}_{2} \mathrm{SO}_{4}$, and filtered and evaporated to remove the solvent. The crude product was obtained and purified chromatographically using silica gel (200-300 mesh, petroleum/ethyl acetate $(\mathrm{v} / \mathrm{v})$ $=20: 1)$. The total yield of the final product, 4-diphenylphosphinostyrene, which was white, was 78\%; the melting point was $79-80{ }^{\circ} \mathrm{C}$, in accord with the value reported in the literature [19].

\subsection{Microcapsule-supported Pd catalyst preparation}

\subsubsection{Preparation of microcapsules with phosphine ligands}

Figure 1 shows the set-up for microcapsule preparation. Poly(methyl methacrylate) plates were used as the microreactor substrates. A quartz capillary (outer diameter $0.70 \mathrm{~mm}$, inner diameter $0.53 \mathrm{~mm}$ ) was embedded in the main channel as the dispersed-phase fluid inlet, and two Teflon tubes were separately embedded in two side channels as the continuous-phase fluid inlets. The continuous-phase fluid was an aqueous solution containing $1.0 \mathrm{wt} \%$ poly(vinyl alcohol) Sinopharm Group Co., Ltd., China; molecular weight 1770) and $0.5 \mathrm{wt} \%$ sodium dodecyl sulfate (SDS). The dispersed-phase fluid consisted of 4-diphenylphosphinostyrene (1.0 mmol, 0.29 g), divinylbenzene (1.30 g, Aladdin Co., Ltd., Shanghai, China), 2,2-azobisisobutyronitrile (3.0 wt\% of total monomer), styrene (5.0 mmol, $0.52 \mathrm{~g}, 99 \%$, Aladdin) and hexadecane (10 wt $\%$ of total monomer). Two syringe pumps were used to feed the continuous-phase fluid and the dispersed-phase fluid separately. A 6-m delay loop was placed in the microreactor thermostat at $98{ }^{\circ} \mathrm{C}$, in which the droplets generated in the microreactor were converted to microcapsules by the free radical polymerization for 4.0-4.3 min. Finally, the collected microcapsules were washed with ethanol and dried under vacuum at room temperature.

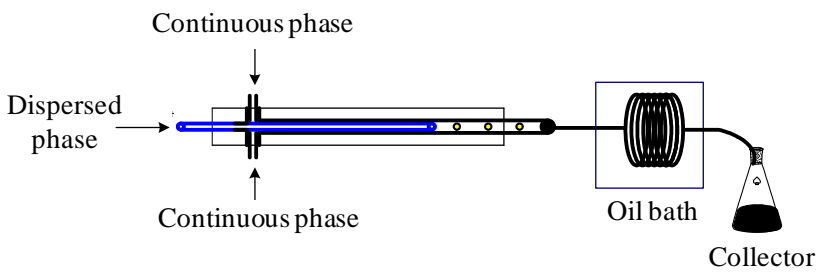

Fig. 1. Set-up for microcapsule preparation. 


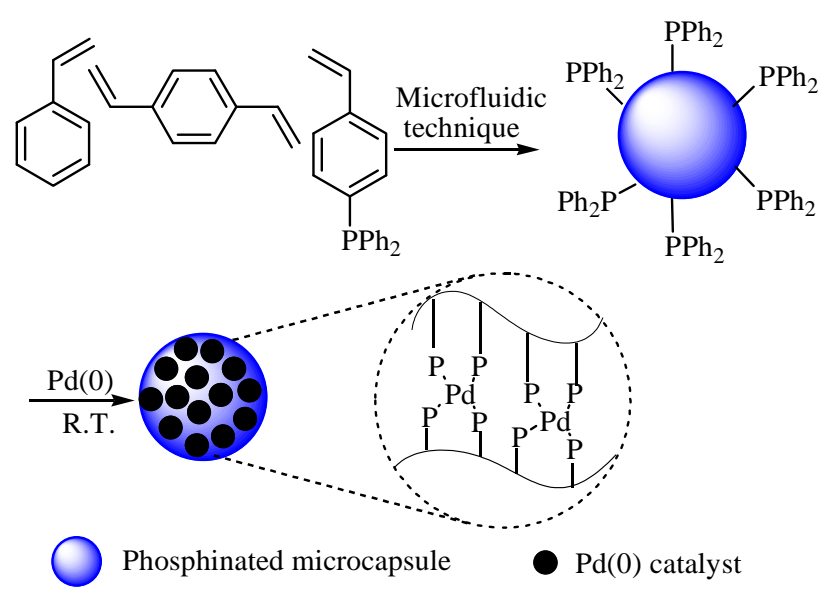

Fig. 2. Schematic diagram of preparation of microcapsule-supported $\mathrm{Pd}(0)$ catalyst (Mac-Pd).

\subsection{2. $\quad P d(0)$ immobilization on microcapsules}

A solution of $\mathrm{Pd}\left(\mathrm{PPh}_{3}\right)_{4}$ (Strem Chemicals; 99\%) in $\mathrm{CH}_{2} \mathrm{Cl}_{2}$ was added to a Schlenk tube containing $1.0 \mathrm{~g}$ of microcapsules under $\mathrm{N}_{2}$, and then stirred for $4 \mathrm{~h}$ at room temperature. The microcapsule-supported $\operatorname{Pd}(0)$ catalyst was then filtered off, washed with $\mathrm{CH}_{2} \mathrm{Cl}_{2}$, and dried under vacuum. Figure 2 shows a schematic diagram of the microcapsule-supported Pd catalyst preparation.

\subsection{Characterization methods}

The microcapsule-supported Pd catalyst was calcined in a muffle furnace at $700{ }^{\circ} \mathrm{C}$ for $2 \mathrm{~h}$. After cooling to room temperature, the catalyst was dissolved in aqua regia (hydrochloric acid/nitric acid $=3: 1, \mathrm{v} / \mathrm{v}$ ) and charged by a constant volume volumetric flask. Inductively coupled plasma atomic emission spectroscopy (ICP-AES; Optima 2000DV) was used to determine the $\mathrm{P}$ and $\mathrm{Pd}$ contents of the catalyst.

Scanning electron microscopy (SEM; JSM-6700) was used for morphology characterization. The samples were plated with gold at $1200 \mathrm{~V}$ and $10 \mathrm{~mA}$ for $3 \mathrm{~min}$ before characterization. The surface composition of the microcapsule was determined using a built-in energy-dispersive X-ray spectroscopy (EDX) facility at an accelerating voltage of $20 \mathrm{kV}$.

The particle size distribution was analyzed using a Malvin 2000 laser particle size analyzer. The samples were dispersed in water by ultrasonic treatment for 2 min before measure- ments. The particle size distribution is expressed by the coefficient of variance (CV), defined as

$$
\mathrm{CV}=\sqrt{\frac{\sum\left(d_{\left.\mathrm{i}-d_{\mathrm{n}}\right)^{2}}\right.}{N d_{\mathrm{n}}^{2}}}
$$

where $d_{\mathrm{i}}$ is the particle size, $d_{\mathrm{n}}$ is the average diameter size, and $N$ is the number of particles.

\subsection{General procedure for Suzuki coupling reaction}

A mixture solution of $1.0 \mathrm{~mol} \%$ catalyst, aryl bromide $(0.25$ mmol, Alfa Aesar), phenyl boronic $(0.38 \mathrm{mmol}$, Alfa Aesar, $98+\%), \mathrm{K}_{2} \mathrm{CO}_{3}$ (0.38 mmol), and dried isopropanol (IPA) was added to a Schlenk tube and then stirred for $4-6 \mathrm{~h}$ at $80{ }^{\circ} \mathrm{C}$. After the reaction was complete, the mixture solution was cooled to room temperature and filtered to remove the catalyst by a microporous membrane with pore size of $2.5 \mu \mathrm{m}$. Acetophenone (Acro; 99.9\%) was then added as an internal standard for quantitative analysis using a gas chromatograph (Agilent GC $6790)$. The recovered catalyst was sequentially washed with $\mathrm{CH}_{2} \mathrm{Cl}_{2}(5 \mathrm{ml} \times 2)$ and ethanol $(5 \mathrm{ml} \times 2)$ for reuse.

\section{Results and discussion}

\subsection{Morphology and particle size of microcapsules}

In the coaxial microreactor, spherical droplets containing phosphine-functionalized monomers of uniform size were generated by microfluidic technique. As the free-radical polymerization reaction progressed, the droplets gradually solidified to form spherical microcapsules (Fig. 3(a)). As seen in Fig. 3(b) and (c), the average diameter could be flexibly adjusted by precisely tuning the flow rates of the two-phase flow, while maintaining uniformity of size. For example, when the flow rate of the continuous phase $\left(Q_{c}\right)$ and the flow rate of the dispersed phase $\left(Q_{\mathrm{d}}\right)$ were 300 and $10 \mu \mathrm{l} / \mathrm{min}$, respectively, the average diameter of the microcapsules was $339 \mu \mathrm{m}$, with a CV of $4.82 \%$ (Fig. 3(b)); when $Q_{\mathrm{d}}$ was increased to 15 or $20 \mu \mathrm{l} / \mathrm{min}$, the average diameter of the microcapsules changed to 378 and $393 \mu \mathrm{m}$, respectively, corresponding to CVs of $4.37 \%$ and $5.49 \%$, respectively. Compared with the microcapsules of diameter of several microns as reported in the literature [6], the microcapsules of diameter of hundreds of microns prepared in this work might be more suitable for use in a fixed-bed reactor rather than a slurry-bed reactor. As is well known, a heteroge-
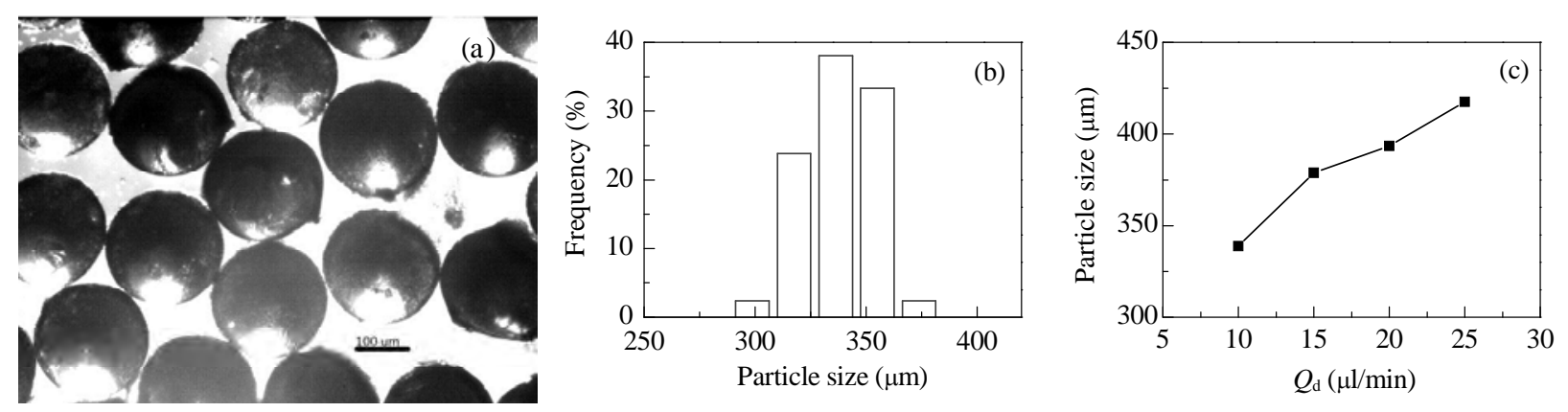

Fig. 3. Microcapsules with phosphorus functional groups. (a) Optical microscopy photograph; (b) Particle size distribution; (c) Changes in particle size with $Q_{\mathrm{d}}$. Typical $Q_{\mathrm{d}}$ and $Q_{\mathrm{c}}$ values were 10 and $300 \mu \mathrm{l} / \mathrm{min}$, respectively. 

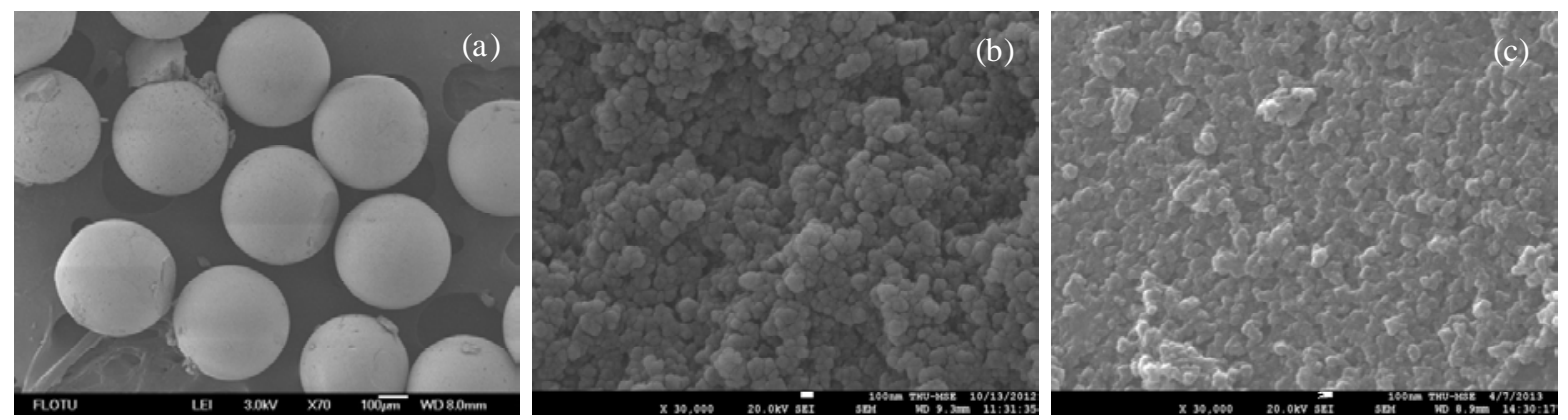

Fig. 4. SEM photographs of microcapsules. (a) Appearance; (b) Section; (c) Section of Pd(0)-containing microcapsules.

neous catalyst in a fixed-bed reactor can be endowed with a higher loading density and better mechanical stability than those in a slurry-bed reactor. Moreover, the productivity and controllability of the microcapsule-supported Pd catalyst could be benefit from the continuous preparation process based on a microfluidic platform.

\subsection{Pd immobilization}

Microcapsules of average diameter $339 \mu \mathrm{m}$ were chosen for homogeneous $\mathrm{Pd}\left(\mathrm{PPh}_{3}\right)_{4}$ immobilization; the catalyst is denoted by Mac-Pd in the following. The morphologies of the microcapsules before and after $\operatorname{Pd}(0)$ immobilization were characterized using SEM, as shown in Fig. 4. The low-magnification SEM photograph (Fig. 4(a)) shows that the prepared microcapsules were well-dispersed spheres with smooth appearance and uniform particle size. The high-magnification SEM photographs of microcapsule sections before and after $\mathrm{Pd}(0)$ immobilization (Fig. 4(b) and (c)) show that the microcapsule was assembled from numerous nano-sized polymeric particles, and their aggregation status changed little after contact with the organic solvent used during the $\mathrm{Pd}(0)$ immobilization process. The similarity between Fig. 4(b) and (c) also implies that the immobilized $\mathrm{Pd}(0)$ is well dispersed. The compositions of the microcapsules before and after $\operatorname{Pd}(0)$ immobilization were characterized using SEM-EDX and ICP-AES. Figure 4 shows the SEM-EDX results. Before $\operatorname{Pd}(0)$ immobilization, the molar fraction of $\mathrm{P}$ in the microcapsule was $0.96 \mathrm{~atm} \%$, corresponding to $1.86 \mathrm{wt} \%$, that was consistent with what determined by ICP-AES (1.79 wt\%). After Pd(0) immobilization, the Pd content of the microcapsules was $1.07 \mathrm{wt} \%$, and the molar ratio of $\mathrm{Pd}$ to P was nearly 1:4 (Fig. 5(b)). These results were consistent with those obtained using ICP-AES. This suggests that Pd immobilization involves coordination of four phosphine ligands with one Pd atom. The stability of the active species within the catalyst would probably benefit from such a high coordination number.

\subsection{Catalytic activity}

Using the reaction conditions reported in the literature [6], the Suzuki coupling reaction of 4-bromoacetophenone with phenylboronic acid was chosen to evaluate the catalytic activity of the microcapsule-supported Pd catalyst. After the reaction was proceeded for $30 \mathrm{~min}$, the mixture will be taken out $0.5 \mathrm{ml}$ every $20 \mathrm{~min}$ for the quantitiative analysis by GC. A plot of the yield versus time using Mac-Pd is shown in Fig. 6. The results using Mic-Pd and $\mathrm{Pd}\left(\mathrm{PPh}_{3}\right)_{4}$ are also plotted in Fig. 6 for comparison. As can be seen, both Mac-Pd and Mic-Pd show higher catalytic activity than the homogenous $\mathrm{Pd}\left(\mathrm{PPh}_{3}\right)_{4}$ catalyst in this reaction. This could be ascribed to the higher concentration of Pd active species on the accessible surface of the microcapsule than in the homogeneous catalyst system [6]. Moreover, the catalytic activity of Mac-Pd (300-400 $\mu \mathrm{m})$ was lower than that of Mic-Pd (7-8 $\mu \mathrm{m})$, but properly prolonging its' reaction time to $4 \mathrm{~h}$, the products' yield was $98 \%$. Thus, the increase of particle size wasn't obvious effect on the apparent kinetics, but the process was mainly controlled by the reaction kinetics. Considering the particle size requirements of heterogeneous catalysts in specific reactors, Mac-Pd with hundreds of microns in size, is more suitable for a fixed-bed reactor than Mic-Pd
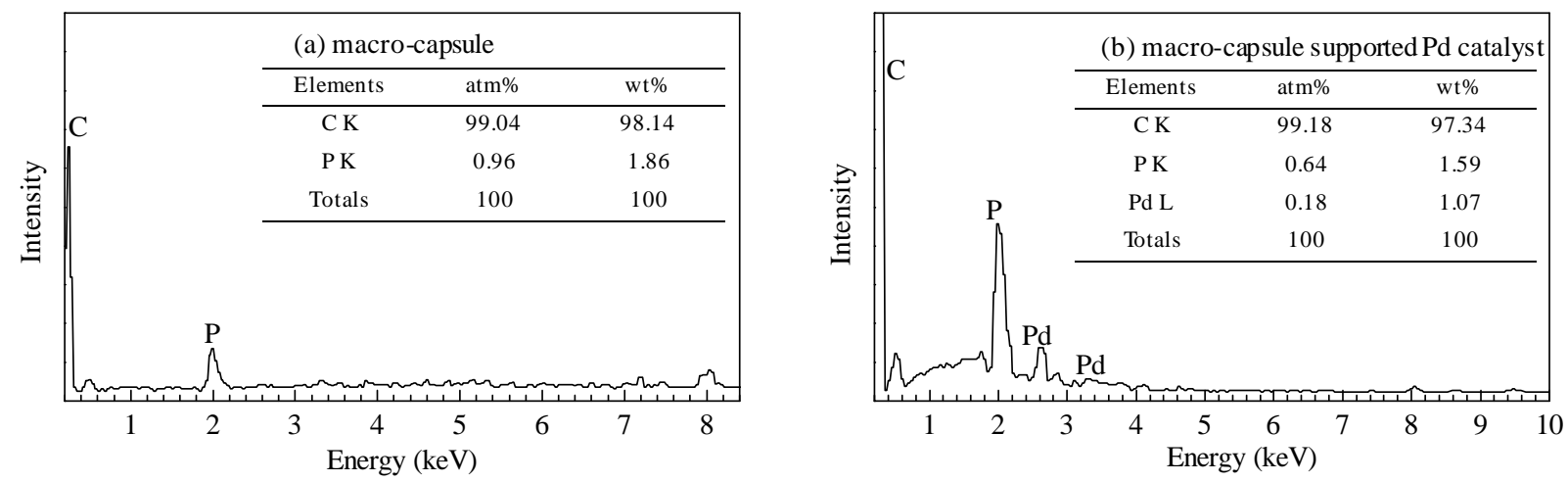

Fig. 5. EDX spectra of microcapsules before (a) and after (b) $\operatorname{Pd}(0)$ immobilization. 


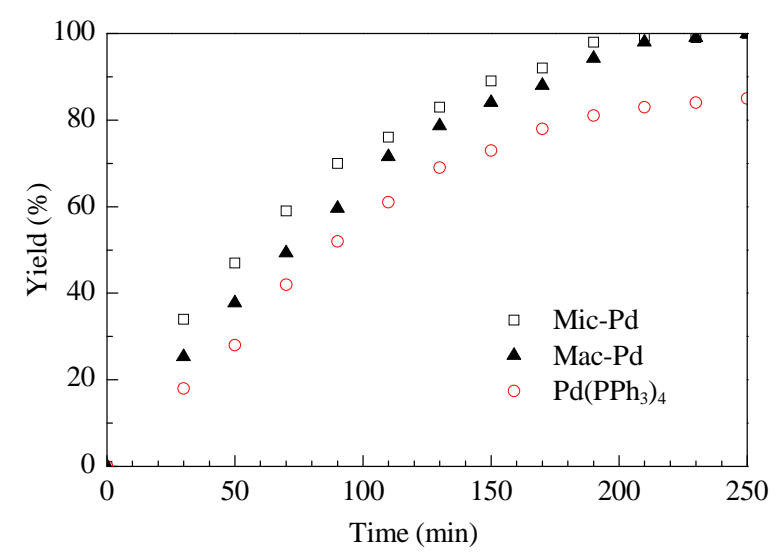

Fig. 6. Yield versus time for Suzuki coupling reaction catalyzed by various Pd catalysts. Reaction conditions: catalyst $1.0 \mathrm{~mol} \%$, 4-bromoacetophenone $0.25 \mathrm{mmol}$, phenylboronic acid $0.38 \mathrm{mmol}, \mathrm{K}_{2} \mathrm{CO}_{3} 0.38$ $\mathrm{mmol}, 80^{\circ} \mathrm{C}$.

with several microns in size, which is more suitable for a slurry-bed reactor, and the fixed-bed reactor will be performed the advantages of high catalyst density and low mechanical loss, compared with the latter. In addition, the catalysis mechanism process and optimization of the microcapsule-supported catalysts needed to be further investigated.

\subsection{Substrate tolerance}

Suzuki reactions were carried out with various aryl bromide derivatives and phenylboronic acid using Mac-Pd as the catalyst. The results are summarized in Table 1 . The reaction of

\section{Table 1}

Mac-Pd-catalyzed Suzuki coupling reaction between aryl bromides and phenylboronic acid.

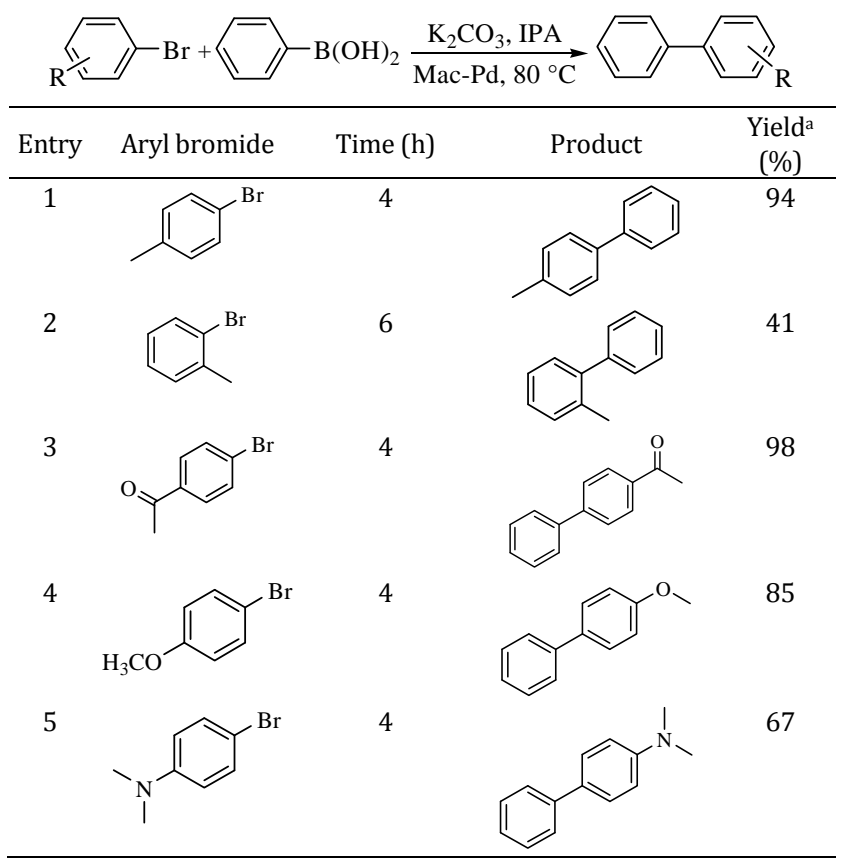

Reaction conditions: aryl bromide $0.25 \mathrm{mmol}$, phenylboronic acid 0.38 $\mathrm{mmol}, \mathrm{K}_{2} \mathrm{CO}_{3} 1.5 \mathrm{mmol}, 1.0 \mathrm{~mol} \%$ Mac-Pd, IPA $2 \mathrm{ml}$, the reaction progress was detected by TLC. a ${ }^{\mathrm{GC}}$ yield with acetophenone as the internal standard.

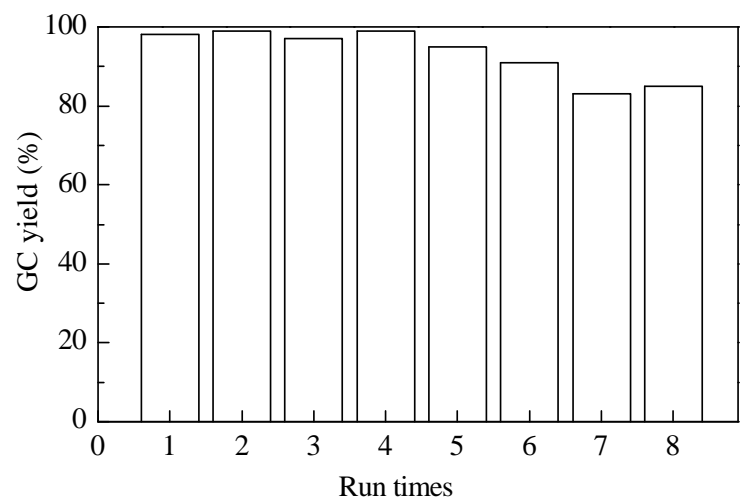

Fig. 7. Reuse of Mac-Pd in the Suzuki coupling reaction of 4'-bromoacetophenone with phenylboronic acid. After the reaction, the catalyst was recovered by simple filtration and washed with THF, $\mathrm{H}_{2} \mathrm{O}$, EtOH for the next cycling.

4-bromotoluene with phenylboronic acid gave a GC yield of $94 \%$ within $4 \mathrm{~h}$ (entry 1). However, 2-bromotoluene as the substrate gave only a $41 \%$ GC yield for a longer time interval (6 h; entry 2) because of steric hindrance by the ortho methyl group. Comparing entries 3-5 shows that the yield of the coupling product was clearly influenced by the nature of the substituent. For substrates bearing electron-withdrawing groups such as $\mathrm{CH}_{3} \mathrm{CO}-$ (entry 3 ) and $\mathrm{CH}_{3} \mathrm{O}-$ (entry 4 ), the yields after reaction for $4 \mathrm{~h}$ were $98 \%$ and $85 \%$, respectively. For substrates bearing electron-donating groups such as $\left(\mathrm{CH}_{3}\right)_{2} \mathrm{~N}-$, the yield was much lower (entries 1 and 5). A possible reason is that $\mathrm{C}-\mathrm{Br}$ bonds' rupture in the substrate bearing electron-withdrawing groups is prone to occur, completing the oxidative-addition reaction between the aryl bromide and the $\operatorname{Pd}(0)$ active species.

\subsection{Catalyst reuse}

The reusability of Mac-Pd was tested using the Suzuki coupling reaction of 4-bromoacetophenone with phenylboronic acid with 4 h each run. The reaction conditions and the results are listed in Fig. 7. Mac-Pd was recovered by simple filtration and was reused six times; the catalytic activity decreased slightly, giving a yield of $98 \%$ in run 1 and a yield of $91 \%$ in run 6. Pd was not detected in the reaction solution by atomic absorption spectrometry (detection limits $<5.0 \mu \mathrm{g} / \mathrm{g}$ ). This indicates that the phosphine ligands anchored on the functionalized microcapsules had good stability during the course of the reaction.

\section{Conclusions}

A new method for the continuous and controllable preparation of a microcapsule-supported Pd catalyst was developed using a microfluidic platform. Specifically, microdroplets containing functional monomers were generated in a coaxial microreactor and subsequently converted to microcapsules in a delay loop placed into a thermostat at $98{ }^{\circ} \mathrm{C}$. Uniform and size-tunable microcapsules hundreds of microns in size were obtained within around $4 \mathrm{~min}$; the microcapsules effectively 


\title{
Graphical Abstract
}

Chin. J. Catal., 2013, 34: 1635-1643 doi: 10.1016/S1872-2067(12)60630-5

Preparation of microcapsule-supported palladium catalyst using a microfluidic platform

Ying Liu, Yangcheng Lü*, Guangsheng Luo

Tsinghua University

Phosphine-functionalized polystyrene microcapsules hundreds of microns in size were continuously prepared using a microfluidic platform. The microcapsules were used to prepare easily recovered, highly efficient, and reusable Suzuki reaction catalysts.

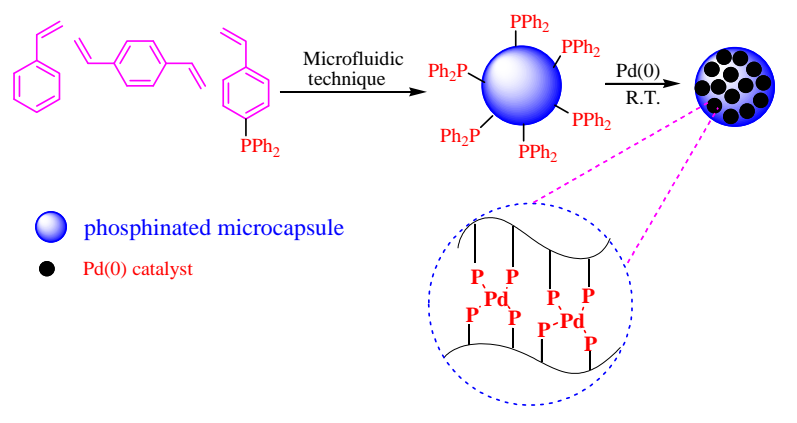

immobilized homogeneous $\mathrm{Pd}$ catalysts such as $\mathrm{Pd}\left(\mathrm{PPh}_{3}\right)_{4}$. For the Suzuki coupling reaction of 4-bromoacetophenone with phenylboronic acid, the microcapsule-supported Pd catalyst (Mac-Pd) showed catalytic activity superior to that of a homogeneous Pd catalyst, similar to reports in the literature [6], although the size of the microcapsule was 50 times higher than that of the reference. The substrate tolerance of Mac-Pd was also verified by catalyzing a series of Suzuki reactions of various aryl bromide derivatives with phenylboronic acid. Mac-Pd was recovered by simple filtration and reused. Both the catalytic activity and the immobilized Pd showed good stability in reusability tests. The productivity and controllability of Mac-Pd benefitted from continuous preparation on a microfluidic platform. Mac-Pd catalysts with hundreds of microns in size are more suitable for a fixed-bed reactor, with specific advantages, including high catalyst density and low mechanical loss, comparing with slurry bed reactor for the micron-sized microcapsule.

\section{References}

[1] Cole-Hamilton D J. Science, 2003, 299: 1702

[2] Leadbeater N E, Marco M. Chem Rev, 2002, 102: 3217

[3] Akiyama R, Kobayashi S. Chem Rev, 2009, 109: 594
[4] Okamoto K, Akiyama R, Kobayashi S. Org Lett, 2004, 6: 1987

[5] Nishio R, Sugiura M, Kobayashi S. Org Lett, 2005, 7: 4831

[6] Liu Y, Feng X J, Bao D C, Li K X, Bao M. J Mol Catal A, 2010, 323: 16

[7] Omi S, Katami K, Yamamoto A, Iso M. J Appl Polym Sci, 1994, 51: 1

[8] Lee J, Hwang D R, Shim S E, Rhym Y M. Macromol Res, 2010, 18: 1142

[9] Luo G S, Lan W J, Li S W, Xu J H, Lu Y C. Petrochem Technol (骆广生, 兰文杰, 李少伟, 徐建鸿, 吕阳成. 石油化工), 2010, 39: 1

[10] Shestopalov I, Tice J D, Ismagilov R F. Lab Chip, 2004, 4: 316

[11] Holtze C, Rowat A C, Agresti J J, Hutchison J B, Angile F E, Schmitz C H J, Köster S, Duan H, Humphry K J, Scanga R A, Johnson J S, Pisignano D, Weitz D A. Lab Chip, 2008, 8: 1632

[12] Chu L Y, Xie R, Ju X J, Liu L, Wang W. Membr Sci Technol (褚良银, 谢锐, 巨晓洁, 刘丽, 汪伟. 膜科学与技术), 2011, 31: 59

[13] Wang J T, Wang J, Han J J. Small, 2011, 7: 1728.

[14] Yang B D, Lu Y C, Luo G S. Ind Eng Chem Res, 2012, 51: 9016

[15] Steibacher J L, Moy R W Y, Price K E, Cummings M A, Roychowdhury C, Buffy J J, Olbricht W L, Haff M, McQuade D T. J Am Chem Soc, 2006, 128: 9442

[16] Liu Z D, Lu Y C, Yang B D, Luo G S. Ind Eng Chem Res, 2011, 50: 11853

[17] Nisisako T, Torii T, Takahashi T, Takizawa Y. Adv Mater, 2006, 18: 1152

[18] Liu Y, Feng X J, Wang Y M, Bao M. J Mol Sci (刘芗, 冯秀娟, 王勇猛, 包明. 分子科学学报), 2010, 26: 159

[19] Choi M K W, He H S, Toy P H.J Org Chem, 2003, 68: 9831

\section{微流控技术制备微胶囊负载钯催化剂}

\author{
刘莹, 吕阳成, 骆广生 \\ 清华大学化学工程系化学工程联合国家重点实验室, 北京100084
}

摘要: 采用微流控技术结合悬浮聚合方法实现了百微米级含膦配体聚苯乙烯微胶囊的可控制备, 微胶囊尺寸在320 420 $\mu \mathrm{m}$ 范围 内可调, 且单分散性好. 扫描电子显微镜、能量散射光谱和电感耦合等离子发射光谱结果证实了其形貌和组成的均匀性及钯负载 的可控性和有效性. 以溴代芳烃与苯硼酸的Suzuki偶联反应为模型反应评价了负载 $\mathrm{Pd}\left(\mathrm{PPh}_{3}\right)_{4}$ 的百微米级微胶囊的催化性能, 发现 其性能与文献报道的7 8 $\mu \mathrm{m}$ 的同类催化剂微胶囊接近, 且均优于均相催化剂; 该催化剂经简单过滤后, 可实现多次循环使用, 未 发现活性物种的流失. 该法实现了连续制备, 因而有助于提高制备的效率和可控性. 另外, 所制百微米级催化剂微胶囊在固定床 反应器内具有较高催化剂浓度和机械性能, 且优于浆态床中使用的微米级催化剂微胶囊.

关键词: 微胶囊; 钯; 负载型催化剂; 微流控技术; 粒径调控; Suzuki偶联反应; 催化活性

收稿日期: 2013-04-29. 接受日期: 2013-05-30. 出版日期: 2013-09-20.

*通讯联系人. 电话/传真: (010)62773017; 电子信箱: luyc@mail.tsinghua.edu.cn 
基金来源：国家自然科学基金(21036002, 21176136); 中国博士后科学基金(2012M520295).

本文的英文电子版由Elsevier出版社在ScienceDirect上出版(http://www.sciencedirect.com/science/journal/18722067).

\section{1. 前言}

与传统的非均相催化剂相比, 胶囊负载型催化剂具 有“复相化均相催化剂”[1]的美誉, 其活性和稳定性较高、 制备成本较低, 具有十分重要的理论研究价值和实际应 用前景. 配体功能化的微胶囊负载的过渡金属催化剂, 已广泛用于 $C-C$ 键形成反应 ${ }^{[2 \sim 4]}$, 表现出高活性、高选择 性以及良好的循环使用性能. Nishio等 ${ }^{[5]}$ 通过聚合物包 埋法制备了聚苯乙烯胶囊固定的 $\mathrm{Pd}\left(\mathrm{PPh}_{3}\right)_{4}$ 催化剂, 用于 甲苯 $/ \mathrm{H}_{2} \mathrm{O}$ 混合溶液中催化Suzuki偶联反应, 回流 $4 \mathrm{~h}$ 后, 产物收率达84\% 96\%. 对于这类胶囊负载型催化剂, 胶 囊的尺寸和形貌会直接影响其催化性能; 实现胶囊催化 剂的形态规整、尺寸均匀对于研究催化反应规律以及机 理探讨十分必要. 最近, Liu等 ${ }^{[6]}$ 利用 SPG 乳化技术 ${ }^{[7,8]}$, 制得含 4-二苯基膦苯乙烯单体的 $\mathrm{O} / \mathrm{W}$ 型乳液液滴, 经悬 浮聚合后, 将颗粒粒径控制在7 10 $\mu \mathrm{m}$, 负载均相钯催化 剂后应用于Suzuki偶联反应, 获得了较高且稳定的催化 活性. 但该过程分乳化和聚合两步进行, 乳液收集时间 较长和启动聚合反应的升温过程较慢, 都会给聚合物颗 粒的形貌和尺寸控制带来不利影响.

近年来发展起来的微流控技术 ${ }^{[9]}$ 具有精确操控微尺

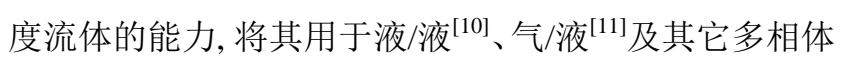
系 ${ }^{[12]}$, 可获得形状、组成和内部结构高度可控的分散相, 不仅可以用于制备尺寸分散系数在 $5 \%$ 以下的微球 ${ }^{[13,14]}$ 和药用微胶囊 ${ }^{[15]}$, 还能实现对聚合物分子量的控制 ${ }^{[16]}$ 和 对微胶囊形态结构的复杂调控 ${ }^{[17]}$.

因此, 本文利用微流控技术提供的均匀、可控的反 应平台, 尝试建立一种连续化、快速制备粒径均匀的微 胶囊负载Pd催化剂的方法, 通过在微通道内原位、连续 地进行液滴分散和聚合反应, 在320 420 $\mu \mathrm{m}$ 范围内实现 了对微胶囊尺寸的灵活和准确调节; 以Suzuki偶联反应 为模型(图式1), 对比分析了微胶囊尺寸对催化活性的影 响, 考察了微胶囊负载钯催化剂的循环使用性能.

\section{2. 实验部分}

\subsection{4-二苯基膦苯乙烯单体的合成}

根据文献[18]报道方法合成4-二苯基膦苯乙烯化合 物. 向装有恒压滴液漏斗的 $250 \mathrm{ml}$ 三口圆底烧瓶中加入 $1.46 \mathrm{~g}$ (60 mmol)镁粉(AR, 国药试剂有限公司)和少量对 苯二酚(AR, 国药试剂有限公司). 在高纯 $\mathrm{N}_{2}$ 下, 向恒压
滴液漏斗中缓慢滴加含 $6.50 \mathrm{ml}$ (50 mmol) 4-溴苯乙烯 (CP, 上海长根化学科技有限公司)的四氢呋喃(THF, AR, 北京化学试剂厂)溶液 $30 \mathrm{ml}$, 反应混合液的温度控制在 $40^{\circ} \mathrm{C}$ 以下. 待镁粉基本消失, 将混合液的温度降至 $-15{ }^{\circ} \mathrm{C}$, 并开始滴加含氯化二苯基膦 $9.4 \mathrm{~g}(50 \mathrm{mmol}, \mathrm{CP}$, 上海长根化学科技有限公司)的 THF溶液 $24 \mathrm{ml}, 2 \mathrm{~h}$ 内滴 加完毕. 缓慢升至室温, 用饱和 $\mathrm{NH}_{4} \mathrm{Cl}$ 水溶液调节 $\mathrm{pH}$ 至 弱酸性, 用乙酸乙酯(AR, 北京化学试剂厂)萃取并分出 有机相. 依次用饱和 $\mathrm{NaHCO}_{3}(\mathrm{AR}$, 北京化学试剂厂)、饱 和食盐水洗涤, 加入无水 $\mathrm{Na}_{2} \mathrm{SO}_{4}$ 干燥, 去除有机溶剂, 获 得粗品. 采用200 300目硅胶柱层层析(展开剂是石油醚 (沸点 $60 \sim 90^{\circ} \mathrm{C}$ ): 乙酸乙酯 $=20: 1$ ), 获得产品. 整个过程 产品收率 $78 \%$, 产品熔点 $79 \sim 80{ }^{\circ} \mathrm{C}$, 与文献一致 ${ }^{[19]}$.

\section{2. 微胶囊负载钯催化剂的制备}

\subsection{1. 含膦配体微胶囊的制备}

图1为采用PMMA板材作为基材制作同轴环管微反 应器, 其中水平通道内嵌入石英毛细管 (外径 $0.70 \mathrm{~mm}$, 内径 $0.53 \mathrm{~mm}$ ) 用于引入分散相流体, 两侧垂直通道嵌入 聚四氟乙烯管用于引入连续相流体. 连续相流体是含 $1.0 \mathrm{wt} \%$ 聚乙烯醇(PVA, 国药集团有限公司, 分子量 1770)和 $0.5 \%$ 二烷基硫酸钠(SDS, AR, 国药集团有限 公司)的去离子水; 分散相流体是含 4-二苯基膦苯乙烯 $(1.0 \mathrm{mmol}, 0.29 \mathrm{~g}) 、$ 二乙烯基苯(1.30 g, 阿拉丁试剂有限 公司)、偶氮二异丁基氰(用量占单体量的 $3.0 \mathrm{wt} \%$, 国药 集团有限公司, 分析纯)、苯乙烯 (5.0 mmol, $0.52 \mathrm{~g}$, 阿拉 丁试剂有限公司, 纯度 $99 \%$ )和正十六烷(占单体总量的 $10 \mathrm{wt} \%)$ 的混合溶液. 两相流体的流量通过注射百调控. 微反应器的出口盘管置于 $98^{\circ} \mathrm{C}$ 的油浴中, 分散相流体 液滴在流经 $6 \mathrm{~m}$ 长的盘管过程中经4.0 4.3 $\mathrm{min}$ 发生自由 基聚合反应, 固化成微胶囊颗粒. 然后取出, 经乙醇洗涤 真空室温干燥后, 备用.

\subsection{2. $\operatorname{Pd}(0)$ 在微胶囊上的负载}

将1.0 g微胶囊加入到 $\mathrm{N}_{2}$ 保护下的Schlenk瓶中, 然后 添加一定量 $\mathrm{Pd}\left(\mathrm{PPh}_{3}\right)_{4}$ (Strem Chemicals, 99\%)的 $\mathrm{CH}_{2} \mathrm{Cl}_{2}$ 溶液, 室温搅拌 $4 \mathrm{~h}$, 使用微孔过滤膜进行分离, 再经 $\mathrm{CH}_{2} \mathrm{Cl}_{2}$ 洗涤和真空干燥, 获得微胶囊负载钯催化剂, 其 制备过程示意图如图2所示.

\section{3. 样品的表征}

将准确称量的微胶囊负载钯催化剂, 置入马弗炉中 于 $700{ }^{\circ} \mathrm{C}$ 焙烧 $2 \mathrm{~h}$, 待冷却至室温后, 用王水(盐酸和硝酸 
的体积比为3:1)溶解, 并用容量瓶定容; 最后, 利用电感 耦合等离子体发射光谱仪(ICP-AES, Optima 2000DV)测 定溶液中的P和Pd含量.

使用扫描电镜(SEM, JSM-6700)和X射线能谱(EDX, JSM-6700)分别对微胶囊的外观形态和表面元素进行表 征. 将微胶囊分散在导电胶带上, 在 $1200 \mathrm{~V}, 10 \mathrm{~mA}$ 条件 进行镀金 3 min 后, 利用SEM观察样品外观形态, 并利用 EDX谱对微胶囊表面进行元素分析, 加速电压 $20 \mathrm{kV}$.

利用马尔文 2000 型激光粒度仪对胶囊颗粒的平均 粒径大小和分布进行检测. 将待测样品加入到去离子水 中, 超声分散 $2 \mathrm{~min}$ 后开始检测. 颗粒的粒径分布用变异 系统(CV)值表示, 计算公式如下:

$$
\mathrm{CV}=\sqrt{\frac{\sum\left(d_{\mathrm{i}}-d_{\mathrm{n}}\right)^{2}}{N d_{\mathrm{n}}^{2}}}
$$

其中, $d_{\mathrm{i}}$ 代表颗粒粒径, $d_{\mathrm{n}}$ 代表平均粒径, $N$ 代表统计的颗 粒个数.

\subsection{Suzuki偶联反应}

将1.0 mol\%的微胶囊负载钯催化剂, $0.25 \mathrm{mmol}$ 对溴 代芳烃 (Alfa Aesar), $0.38 \mathrm{mmol}$ 苯嗍酸 (Alfa Aesar, $98+\%), 0.38 \mathrm{mmol} \mathrm{K}_{2} \mathrm{CO}_{3}$ 和干燥的异丙醇同时加到 $\mathrm{N}_{2}$ 下 的Schlenk瓶中, 于 $80^{\circ} \mathrm{C}$ 反应 $4 \sim 6 \mathrm{~h}$ 后, 利用 $2.5 \mu \mathrm{m}$ 孔径的 微孔过滤膜进行分离, 收集滤液, 加入定量苯乙酮(Acro, 99.9\%)作内标物, 采用安捷伦GC 6790型色谱仪对偶联 产物进行定量分析. 简单过滤后, 回收的催化剂依次用 $\mathrm{CH}_{2} \mathrm{Cl}_{2}(5 \mathrm{ml} \times 2)$ 和乙醇 $(5 \mathrm{ml} \times 2)$ 洗涤后用于下一次反 应.

\section{3. 结果与讨论}

\section{1. 微胶囊的形态和粒径}

在同轴环管式微反应器内, 利用微流控技术可以得 到粒径均一的球形液滴, 液滴聚合固化后得到的微胶囊 球形度和单分散性良好, 尺寸在数百微米且可控, 结果 如图3所示. 在实验条件下, 微胶囊呈规整的球形, 粒径 普遍在 $200 \mu \mathrm{m}$ 以上. 随着分散相流量的增加, 其粒径大 小呈增加趋势: 当分散相流量为 $10 \mu \mathrm{l} / \mathrm{min}$, 连续相流量 为 $300 \mu \mathrm{l} / \mathrm{min}$ 时, 微胶囊的平均粒径为 $339 \mu \mathrm{m}, \mathrm{CV}$ 值是 $4.82 \%$; 当分散相流量分别增加到 15 和 $20 \mu \mathrm{l} / \mathrm{min}$ 时, 微胶 囊的平均粒径分别为 379 和 $393 \mu \mathrm{m}, \mathrm{CV}$ 值分别为 $4.37 \%$ 和 $5.49 \%$. Liu等 ${ }^{[6]}$ 利用膜乳化法制备7 10 $\mu \mathrm{m}$ 的微胶囊, 相比而言, 本文方法可以实现连续制备, 这无疑将提高 制备的效率和可控性; 且所制微胶囊的尺寸在亚毫米量 级, 更适合在固定床反应器内使用, 与浆态床反应器相
比, 固定床反应器的催化剂不易出现与结构破坏有关的 失活现象.

\section{2. 钯的负载}

均相催化剂 $\mathrm{Pd}\left(\mathrm{PPh}_{3}\right)_{4}$ 通过配体交换法负载在平均 粒径为339 $\mu \mathrm{m}$ 的微胶囊颗粒上, 获得了微胶囊负载钯催 化剂(记为Mac-Pd), 图4和图5分别比较了微胶囊负载前 后内部结构和组分的变化. 由图4可见, 微胶囊外表面光 滑, 球形度良好, 粒径均一, 颗粒之间没有粘连现象. 将 微胶囊切片之后, 其内部结构呈纳米颗粒的堆积状态, EDX分析表明, 合成的胶囊颗粒上含有有机膦基团, 其 中 P 的摩尔含量是 $0.96 \mathrm{~atm} \%$, 质量含量是 $1.86 \%$, 与 ICP-AES 的检测结果 $(1.79 \%)$ 基本一致. 微胶囊负载 $\operatorname{Pd}\left(\mathrm{PPh}_{3}\right)_{4}$ 后(图4(c)), 微颗粒内部结构未受到负载过程中 有机溶剂的明显影响, 且 $\mathrm{Pd}\left(\mathrm{PPh}_{3}\right)_{4}$ 均匀负载在微颗粒内 部, Pd负载量是 $1.07 \%, \mathrm{Pd} / \mathrm{P}$ 摩尔比约为 $1 / 4$, 与ICP-AES 结果基本一致. 由此推测, 金属 $\mathrm{Pd}$ 原子周围存在 4 个 $\mathrm{P}$ 原 子与之配位, 较高的配位数有助于负载在微胶囊上的金 属活性物种在使用中保持稳定.

\section{3. 催化活性}

图6考察了微胶囊负载Pd催化剂上4-溴苯乙酮与苯 硼酸的Suzuki偶联反应活性. 反应30 min后, 每隔 $20 \mathrm{~min}$ 取样 $0.5 \mathrm{ml}$, 进行定量分析. 由图5可见, 产物产率随着反 应时间的延长而提高; 其中负载后的微胶囊Pd催化剂 Mac-Pd和 Mic-Pd催化活性高于均相 $\mathrm{Pd}\left(\mathrm{PPh}_{3}\right)_{4}$. 这可能 是由于负载型催化剂局部空间 $\operatorname{Pd}(0)$ 活性中间体浓度增 大, 使局部催化转化效率提高所致 ${ }^{[6]}$. 另外, Mic-Pd催化 剂(7 8 $\mu \mathrm{m})$ 活性略高于Mac-Pd (300 400 $\mu \mathrm{m})$, 但通过适 当延长后者的反应时间至 $4 \mathrm{~h}$, 产物收率达 $98 \%$, 与 Mic-Pd的相当. 由此可见, 颗粒尺寸的增大对反应表观 动力学的影响不大, 该过程主要受反应动力学控制. 大 尺寸的微胶囊负载钯催化剂可在固定床反应器中使用, 与微米级微胶囊催化剂适用的浆态床反应器相比, 其在 催化剂加入量和机械可靠性上更高. 此外, 针对微胶囊 负载钯催化剂, 催化过程机制和催化剂优化等都还有待 进一步研究.

\section{4. 反应底物适应性}

以溴代芳烃与苯硼酸的Suzuki偶联反应为研究对 象, 考察了 Mac-Pd催化剂对底物官能团的适应性, 结果 见表1. 可以看出, 当4-溴甲苯与苯硼酸反应 $4 \mathrm{~h}$, 偶联反 应产物的GC收率达 $94 \%$ (表1, 实验 1 ). 然而, 当2-溴甲苯 作反应底物时, 反应长达 $6 \mathrm{~h}$, 偶联产物的收率仅为 $41 \%$ (实验2), 这是由于 2 -位甲基的存在使得溴代芳烃受 
到较大的空间位阻作用所致. 溴代芳烃底物芳环上含有 吸电子基 $\mathrm{CH}_{3} \mathrm{C}(\mathrm{O})-$ 和 $\mathrm{CH}_{3} \mathrm{O}-$ (实验 3 和 4 )时, 产物收率 分别为 $98 \%$ 和 $85 \%$, 高于含供电子基溴代芳烃的(实验 1 和5). 这可能是由于在Mac-Pd催化含吸电子基的溴代芳 烃时, 底物中的C-Br键更易断裂, 有利于 $\operatorname{Pd}(0)$ 活性物种 与之发生氧化加成反应.

\section{5. 循环使用性能}

以 $\mathrm{K}_{2} \mathrm{CO}_{3}$ 为碱, IPA作溶剂, 于 $80^{\circ} \mathrm{C}$ 用 $1.0 \mathrm{~mol} \%$ 的 Mac-Pd催化4-澳苯乙酮与苯硼酸的Suzuki偶联反应, 考 察了微胶囊Pd催化剂Mac-Pd的循环使用性能, 每次反应 $4 \mathrm{~h}$, 结果见图7. 可以看出, 经简单过滤后, Mac-Pd循环 使用4次, 其催化活性未见明显下降, 偶联产物联苯苯乙 酮的产率保持在 $97 \%$ 99\%, 至5次后才有所下降. 反应 结束后, 对滤液进行酸化处理, 利用原子吸收光谱没有
检测到滤液中Pd的存在(检测限 $5 \mu \mathrm{g} / \mathrm{g}$ ). 可见, 微胶囊上 的有机膦配体对过渡金属Pd具有较强的稳定作用.

\section{4. 结论}

利用微流控平台可控制备了微胶囊负载钯催化剂, 在4-溴苯乙酮与苯硼酸的Suzuki偶联反应中表现出比均 相Pd更高的催化活性, 与文献相关值相当. 该催化剂对 一系列溴代芳烃与苯嗍酸参与的Suzuki偶联反应均有适 应性, 经简单过滤后循环使用4次, 其活性未见明显下降, 且未检测到 Pd的流失. 该方法实现了连续制备, 有助于 提高制备的效率和可控性. 同时本文得到的百微米级别 催化剂微胶囊适合在固定床反应器内使用, 与需在浆态 床中使用的微米级催化剂微胶囊相比, 在反应体系催化 剂浓度和机械可靠性上更具优势. 